\title{
Evaluation of Factors Affecting Enuresis in 6- to 12-Year-Old Children Referred to the Pediatric Nephrology Clinic
}

\author{
Anoush Azarfar $^{1} \quad$ Alireza Ghodsi $^{2}$ Farnoosh Faravani $^{3} \quad$ Sara Ghahremani ${ }^{4}$
}

${ }^{1}$ Kidney Transplantation Complications Research Center, Mashhad University of Medical Sciences, Mashhad, Iran

2 Student Research Committee, Faculty of Medicine, Mashhad University of Medical Sciences, Mashhad, Iran

${ }^{3}$ Student Research Committee, Faculty of Dentistry, Mashhad University of Medical Sciences, Mashhad, Iran

${ }^{4}$ Department of Pediatrics, Faculty of Medicine, Mashhad University of Medical Sciences, Mashhad, Iran

J Child Sci 2021;11:e83-e88.
Address for correspondence Sara Ghahremani, Faculty of Medicine, Mashhad University of Medical Sciences, Azadi Square, Mashhad 91766-99199, Iran (e-mail: ghahremanis@mums.ac.ir).

\begin{abstract}
Enuresis is one of the most common disorders in children, and if left untreated can cause anxiety, low self-esteem, and family problems. The aim of this study was to investigate the factors associated with enuresis to provide recommendations for more efficient prevention and treatment. A cross-sectional study was performed on children aged 6 to 12 years with enuresis, referred to the pediatric clinic between April 2017 and April 2018. Children were divided into two groups: monosymptomatic enuresis and healthy subjects. Then, a questionnaire was completed by their parents to assess the factors related to enuresis. The data were analyzed using SPSS software. In this study, out of 140 children with an average age of $8.22 \pm 2.01$ years, 77 cases (55\%) had enuresis, of which 57 (40.7\%) had primary enuresis, and 20 cases (14.3\%) had secondary enuresis. There was a significant difference between the control and the case groups in terms of: father's education, family income, family history, number of people sleeping in the room, family problems, problems at school, history of urinary

Keywords

- enuresis

- factors

- drowsiness

- children tract infections, history of pinworms, difficulty falling asleep, difficulty in waking up, feeling tired after waking up, and drowsiness during the day. Enuresis is associated with several physiological, psychological, and genetic factors. Controlling these factors requires paying attention to the elements such as the mental health of the family and child's sleep health through education, family awareness, and counseling.
\end{abstract}

\section{Introduction}

Enuresis is a common urological complaint in children, which is defined as an involuntary loss of urine during sleep, occurring at least twice a week for at least 3 months in children older than 5 years. ${ }^{1-3}$ According to the classification provided by the International Children's Continence Society,

received

October 3, 2020

accepted after revision

March 5, 2021
DOI https://doi.org/

10.1055/s-0041-1728728.

ISSN 2474-5871. enuresis is divided into primary and secondary. ${ }^{4}$ Secondary enuresis is in children who have had a previous dry period $>6$ months; otherwise, it is called primary enuresis. ${ }^{4}$ Further, enuresis can be classified in terms of the presence or absence of lower urinary tract symptoms and bladder dysfunction. ${ }^{4}$ If the child does not have lower urinary tract
(C) 2021. The Author(s).

This is an open access article published by Thieme under the terms of the Creative Commons Attribution License, permitting unrestricted use, distribution, and reproduction so long as the original work is properly cited. (https://creativecommons.org/licenses/by/4.0/)

Georg Thieme Verlag KG, Rüdigerstraße 14, 70469 Stuttgart, Germany 
symptoms and bladder dysfunction, it is monosymptomatic enuresis, and if any lower urinary tract symptoms present, it is a nonmonosymptomatic enuresis. ${ }^{4}$

The prevalence of enuresis in boys is twice as high as in girls and varies according to age, where approximately $15 \%$ of 7-year-old children ${ }^{5}$ and $10 \%$ of 10 -year-old children suffer from this problem. ${ }^{6}$

Annually, approximately $15 \%$ of patients recover spontaneously, ${ }^{3}$ so that the prevalence among adolescents reaches $2 \%{ }^{7}$ but still, 0.5 to $1 \%$ of adults suffer from enuresis. ${ }^{8}$ In cases with persistent family stress, the prognosis is worse. ${ }^{9}$ Daytime incontinence is less common, girls are more likely to suffer from daytime wetting, and it is rarely seen after the age of 9.10,11

The exact cause of enuresis has not yet been determined, but several factors such as decreased bladder capacity and growth retardation, nocturnal polyuria, sleep disorders, psychological problems, genetics, sex, family socioeconomic status, family size, deep sleep, abnormal daily secretion of antidiuretic hormone, the presence of nocturnal snoring, and obstructive respiratory problems in sleep may be involved in its occurrence. ${ }^{10,12-15}$

Enuresis is a prime concern for the parents because it can cause developmental and psychological damages to the child and hinder the peace of the family. ${ }^{16}$ Therefore, it reduces the quality of life of the child and the family. ${ }^{17}$

Considering the prevalence of enuresis, as well as its negative impacts on the self-image, school performance, and social skills of children, we intended to study the frequency distribution of factors related to enuresis in children aged 6 to 12 years who referred to the Pediatric Nephrology Clinic of Mashhad University of Medical Sciences (Mashhad, Iran).

\section{Method}

This cross-sectional study was performed on children aged 6 to 12 years from April 2017 to April 2018 at the Pediatric Nephrology Clinic of Dr. Sheikh Hospital, affiliated with the Mashhad University of Medical Sciences (Mashhad, Iran).

All children with a diagnosis of monosymptomatic enuresis were recruited, and children with bladder dysfunction, neurogenic bladder, vesicoureteral reflux, spinal dysraphism, myelomeningocele, and daytime incontinence were excluded. An almost equal number of children of the same age who did not have enuresis, referred for other reasons such as checkups or minor issues, was recruited as control. Parents were advised about the details of the study, and after obtaining the informed consent, a written questionnaire was completed by the parents on site. All questions of the questionnaire were explained to the parents by their physician. Collected data were analyzed by IBM SPSS software version 22.0. The mean, standard deviation, median, central tendency, statistical dispersion, and frequency were used to describe the data. A $t$-test was used to compare quantitative variables, and, if necessary, nonparametric methods were applied. Chi-square or Fisher's test was used to determine independence between two dichotomous categorical variables. A logistic regression analysis was done to see how different factors affect the incidence of enuresis and calculate the odds ratio. A p-value of less than 0.05 was considered statistically significant. The study protocol was fully approved by the Ethics Committee of Mashhad University of Medical Sciences (\#IR.MUMS.fm.REC.1396.49).

\section{Results}

In this study, 140 children with a mean age of $8.22 \pm 2.01$ years were examined: 77 cases (55\%) in the case group with enuresis and 63 cases (45\%) in the control group. Out of the 77 children in the enuresis group, 57 (40.7\% of total) had primary enuresis, and 20 (14.3\%) suffered from secondary enuresis. The study population was composed of 69 (49.3\%) boys and 71 (50.7\%) girls.

As listed in - Table 1, the mean age ( $p$ : 0.46), sex frequency ( $p$ : 0.30), and mother's education level ( $p: 0.51)$ showed no significant difference between the two groups. In contrast, the father's education level ( $p: 0.001)$ and the income level ( $p: 0.02$ ) in the case group were significantly higher than in the control group. The number of children in the family was not significantly associated with enuresis ( $p$ : 052); in contrast, there was a significant relationship in terms of birth order, so that in the case group, the highest percentage was for the first child of the family.

As illustrated in - Table 2, a family history of enuresis was significantly higher in the enuresis group ( $p$ : 0.001), and the number of cases with a history of enuresis in siblings was higher than in parents. Although children with enuresis had a higher history of family problems and school problems than the control group, the variable of violent behavior at school did not have a significant association with enuresis ( $p: 0.11)$. In children with enuresis, the history of urinary tract infection ( $p: 0.04$ ) and Oxyuris ( $p: 0.04$ ) was significantly higher. Although constipation was also more common in this group, it was not statistically significant ( $p$ : 0.06).

The cases were also examined for drinking habits, whether they drink a variety of beverages (tea, sweet, and caffeinated beverages). We found that $58.9 \%$ of cases were accustomed to drinking tea and $44.5 \%$ to drinking sweet beverages more than $200 \mathrm{~mL}$ per day, but no significant relationship with enuresis was observed ( $p: 0.12, p: 0.72)$.

In this study, we also investigated the relationship between sleep disorders and enuresis. As shown in -Table 3, the frequency of difficulty falling asleep $(p<0.001)$, difficulty to walk after waking up ( $p: 0.006)$, difficulty in waking up $(p<0.001)$, feeling tired after waking up $(p<0.001)$, and drowsiness during the day $(p<0.001)$ were all significantly higher in the enuresis group. The study also looked at other sleep disorders, including respiratory problems during sleep, apnea, nocturnal snoring, nightmare, sleep talking, sweating during sleep, and bruxism. None of them had a significant difference between the case and the control groups.

As illustrated in -Table 4, a logistic regression analysis showed that the variables of (having) family problems, problems in school, history of urinary tract infection, difficulty falling asleep after waking up, difficulty walking after waking up, difficulty waking a child up, feeling tired after waking up, and drowsiness during the day significantly increase the 
Table 1 Demographic information and comparison of case and control groups

\begin{tabular}{|c|c|c|c|c|c|}
\hline \multicolumn{2}{|l|}{ Variable } & Total & Case group & Control group & Test result \\
\hline \multicolumn{2}{|l|}{ Age average (y) } & $8.22 \pm 2.01$ & $8.11 \pm 1.92$ & $8.36 \pm 2.11$ & $p: 0.46, t: 0.74$ \\
\hline \multicolumn{2}{|l|}{ Frequency of boys } & $69(49.3 \%)$ & $41(53.2 \%)$ & $28(44.4 \%)$ & \multirow[t]{2}{*}{ p: 0.3, chi-square: 1.07} \\
\hline \multicolumn{2}{|l|}{ Frequency of girls } & $71(50.7 \%)$ & $36(46.8 \%)$ & $35(55.6 \%)$ & \\
\hline \multirow[t]{4}{*}{ Birth order } & First & $53(39 \%)$ & $37(48.7 \%)$ & $16(26.7 \%)$ & \multirow[t]{4}{*}{ p: 0.001 , chi-square: 16.24} \\
\hline & Second & $50(36.8 \%)$ & $17(22.4 \%)$ & $33(55 \%)$ & \\
\hline & Third & $23(19.9 \%)$ & $14(18.4 \%)$ & $9(15 \%)$ & \\
\hline & Fourth or more & $10(7.4 \%)$ & $8(10.5 \%)$ & $2(3.3 \%)$ & \\
\hline \multirow[t]{4}{*}{ Mother's level of education } & Elementary school & $36(26.3 \%)$ & $18(23.7 \%)$ & $18(29.5 \%)$ & \multirow[t]{4}{*}{$p: 0.51$, chi-square: 2.93} \\
\hline & Middle school & $29(21.2 \%)$ & $17(22.4 \%)$ & $12(19.7 \%)$ & \\
\hline & High school & $55(40.1 \%)$ & $29(38.2 \%)$ & $26(42.6 \%)$ & \\
\hline & University & $17(12.4 \%)$ & $12(15.8 \%)$ & $5(8.2 \%)$ & \\
\hline \multirow[t]{4}{*}{ Father's level of education } & Elementary school & $46(33.1 \%)$ & $25(32.5 \%)$ & $21(33.9 \%)$ & \multirow[t]{4}{*}{ p: 0.001, chi-square: 17.1} \\
\hline & Middle school & $37(26.6 \%)$ & $11(14.3 \%)$ & $26(41.9 \%)$ & \\
\hline & High school & $44(33.7 \%)$ & $32(41.6 \%)$ & $12(19.4 \%)$ & \\
\hline & University & $12(8.6 \%)$ & $9(11.7 \%)$ & $3(4.8 \%)$ & \\
\hline \multirow[t]{3}{*}{ Income level } & Low & $65(47.1 \%)$ & $28(36.4 \%)$ & $37(60.7 \%)$ & \multirow[t]{3}{*}{$p: 0.02$, chi-square: 8.02} \\
\hline & Moderate & $67(48.6 \%)$ & 45 (58.4\%) & $22(36.1 \%)$ & \\
\hline & High & $6(4.3 \%)$ & $4(5.2 \%)$ & $2(3.3 \%)$ & \\
\hline
\end{tabular}

chance of suffering from enuresis. The positive family history of enuresis also increased the incidence of enuresis.

The results indicate that children with a history of urinary tract infections are 2.11 times more susceptible to developing enuresis ( $p$ : 0.04). In addition, in cases with a history of family problems, enuresis is 7.59 times more likely than in those with no family history $(p<0.001)$.

\section{Discussion}

Enuresis is one of the most common developmental disorders in childhood that may lead to social and emotional problems for children as well as their families. The etiology of enuresis is multifactorial with complex interactions of physiological, psychological, and genetic factors. ${ }^{3}$

Table 2 History of previous illnesses, habits, and accompanying problems

\begin{tabular}{|c|c|c|c|c|c|}
\hline \multicolumn{2}{|l|}{ Variable } & Total & Case group & Control group & Test result \\
\hline \multirow[t]{4}{*}{ Family history of enuresis } & No & 78 (55.7\%) & $33(42.8 \%)$ & 45 (71.4\%) & \multirow[t]{4}{*}{ p: 0.001 , chi-square: 16.27} \\
\hline & Mother & $10(7.1 \%)$ & $4(5.2 \%)$ & $6(9.5 \%)$ & \\
\hline & Father & $15(10.7 \%)$ & $11(14.3 \%)$ & $4(6.3 \%)$ & \\
\hline & Siblings & $37(26.4 \%)$ & $29(37.7 \%)$ & $8(12.7 \%)$ & \\
\hline \multirow[t]{2}{*}{ History of family problems } & Yes & $31(23.3 \%)$ & $27(36.0 \%)$ & $4(6.9 \%)$ & \multirow[t]{2}{*}{$p<0.001$, chi-square: 15.49} \\
\hline & No & $102(76.7 \%)$ & $48(64.0 \%)$ & $54(93.1 \%)$ & \\
\hline \multirow[t]{2}{*}{ History of school problems } & Yes & $26(20.3 \%)$ & $22(30.6 \%)$ & $4(7.1 \%)$ & \multirow[t]{2}{*}{ p: 0.002 , chi-square: 10.66} \\
\hline & No & $102(79.7 \%)$ & $50(69.4 \%)$ & $52(92.9 \%)$ & \\
\hline \multirow[t]{2}{*}{ History of violent behavior at school } & Yes & $16(12.6 \%)$ & $12(16.9 \%)$ & $4(7.1 \%)$ & \multirow[t]{2}{*}{ p: 0.11 , chi-square: 2.71} \\
\hline & No & $111(87.4 \%)$ & $59(83.1 \%)$ & $52(92.9 \%)$ & \\
\hline \multirow[t]{2}{*}{ History of constipation } & Yes & $43(32.3 \%)$ & $30(39.5 \%)$ & $13(22.8 \%)$ & \multirow[t]{2}{*}{ p: 0.06 , chi-square: 4.13} \\
\hline & No & $90(67.7 \%)$ & $46(60.5 \%)$ & $44(77.2 \%)$ & \\
\hline \multirow[t]{2}{*}{ History of urinary tract infection } & Yes & $56(42.7 \%)$ & $37(50.7 \%)$ & $19(32.8 \%)$ & \multirow[t]{2}{*}{ p: 0.04 , chi-square: 4.24} \\
\hline & No & 75 (57.3\%) & $36(49.3 \%)$ & $39(67.2 \%)$ & \\
\hline \multirow[t]{2}{*}{ History of Oxyuris } & Yes & $8(7.8 \%)$ & $7(13.0 \%)$ & $1(2.0 \%)$ & \multirow[t]{2}{*}{ p: 0.04 , chi-square: 4.27} \\
\hline & No & 95 (92.2\%) & $47(87.0 \%)$ & $48(98 \%)$ & \\
\hline
\end{tabular}


Table 3 Sleep disorders

\begin{tabular}{|c|c|c|c|c|c|}
\hline \multicolumn{2}{|l|}{ Variable } & Total & Case group & Control group & Test result \\
\hline \multirow[t]{2}{*}{ Difficulty falling asleep } & Yes & $35(28.7 \%)$ & $29(42.0 \%)$ & $6(11.3 \%)$ & \multirow[t]{2}{*}{$p<0.001$, chi-square: 13.82} \\
\hline & No & $87(71.3 \%)$ & $40(58.0 \%)$ & $47(88.7 \%)$ & \\
\hline \multirow[t]{2}{*}{ Waking up during sleep } & Yes & $50(41.0 \%)$ & $32(45.7 \%)$ & $18(34.6 \%)$ & \multirow[t]{2}{*}{ p: 0.22 , chi-square: 1.50} \\
\hline & No & $72(59.0 \%)$ & $38(54.3 \%)$ & $34(65.4 \%)$ & \\
\hline \multirow[t]{2}{*}{ Waking up often } & One-two times & $38(65.5 \%)$ & $23(69.7 \%)$ & $15(60.0 \%)$ & \multirow[t]{2}{*}{ p: 0.44 , chi-square: 59} \\
\hline & More than two times & $20(34.5 \%)$ & $10(30.3 \%)$ & $10(40.0 \%)$ & \\
\hline \multirow{2}{*}{$\begin{array}{l}\text { Difficulty waking } \\
\text { a child up }\end{array}$} & Yes & $45(35.4 \%)$ & $35(49.3 \%)$ & $10(17.9 \%)$ & \multirow[t]{2}{*}{$p<0.001$, chi-square: 13.52} \\
\hline & No & $82(64.6 \%)$ & $36(50.7 \%)$ & $46(82.1 \%)$ & \\
\hline \multirow{2}{*}{$\begin{array}{l}\text { After waking up, } \\
\text { it is difficult to walk }\end{array}$} & Yes & $16(13.4 \%)$ & $14(21.2 \%)$ & $2(3.8 \%)$ & \multirow[t]{2}{*}{ p: 0.006 , chi-square: 7.68} \\
\hline & No & $103(86.6 \%)$ & $52(78.8 \%)$ & $51(96.2 \%)$ & \\
\hline \multirow{2}{*}{$\begin{array}{l}\text { History of respiratory } \\
\text { problems in sleep }\end{array}$} & Yes & $7(5.6 \%)$ & $6(8.5 \%)$ & $1(1.9 \%)$ & \multirow[t]{2}{*}{ p: 0.24 , chi-square: 2.45} \\
\hline & No & 117 (94.4\%) & 65 (91.5\%) & $52(98.1 \%)$ & \\
\hline \multirow{2}{*}{$\begin{array}{l}\text { Apnea history } \\
\text { during sleep }\end{array}$} & Yes & $5(4.4 \%)$ & $3(5.0 \%)$ & $2(3.8 \%)$ & \multirow[t]{2}{*}{ p: 0.99 , chi-square: 0.10} \\
\hline & No & $108(95.6 \%)$ & $57(95.0 \%)$ & $51(96.2 \%)$ & \\
\hline \multirow[t]{2}{*}{ Night snoring history } & Yes & $21(16.9 \%)$ & $15(21.7 \%)$ & $6(10.9 \%)$ & \multirow[t]{2}{*}{ p: 0.11 , chi-square: 2.55} \\
\hline & No & $103(83.1 \%)$ & $54(78.3 \%)$ & $49(89.1 \%)$ & \\
\hline \multirow[t]{2}{*}{ Nightmare history } & Yes & $27(21.4 \%)$ & $19(27.1 \%)$ & $8(14.3 \%)$ & \multirow[t]{2}{*}{ p: 0.08 , chi-square: 3.05} \\
\hline & No & $99(78.6 \%)$ & $51(72.9 \%)$ & $48(85.7 \%)$ & \\
\hline \multirow{2}{*}{$\begin{array}{l}\text { History of talking } \\
\text { during sleep }\end{array}$} & Yes & $42(33.1 \%)$ & $28(39.4 \%)$ & $14(25.0 \%)$ & \multirow[t]{2}{*}{ p: 0.09, chi-square: 2.95} \\
\hline & No & 85 (66.9\%) & $43(60.6 \%)$ & $42(75.0 \%)$ & \\
\hline \multirow[t]{2}{*}{ History of bruxism } & Yes & $30(25.2 \%)$ & $19(30.2 \%)$ & $11(19.6 \%)$ & \multirow[t]{2}{*}{ p: 0.19 , chi-square: 1.74} \\
\hline & No & $89(74.8 \%)$ & $44(69.8 \%)$ & $45(80.4 \%)$ & \\
\hline \multirow[t]{2}{*}{ Sweating during sleep } & Yes & $27(21.3 \%)$ & $19(26.8 \%)$ & $8(14.3 \%)$ & \multirow[t]{2}{*}{ p: 0.08, chi-square: 2.91} \\
\hline & No & $100(78.7 \%)$ & $52(73.2 \%)$ & $48(85.7 \%)$ & \\
\hline \multirow{2}{*}{$\begin{array}{l}\text { Feeling tired after } \\
\text { waking up }\end{array}$} & Yes & $39(30.7 \%)$ & $32(45.1 \%)$ & 7 (12.5\%) & \multirow[t]{2}{*}{$p<0.001$, chi-square: 15.61} \\
\hline & No & $88(69.3 \%)$ & 39 (54.9\%) & $49(87.5 \%)$ & \\
\hline \multirow{2}{*}{$\begin{array}{l}\text { Drowsiness during } \\
\text { the day }\end{array}$} & Yes & $16(12.6 \%)$ & $15(21.1 \%)$ & $1(1.8 \%)$ & \multirow[t]{2}{*}{$p<0.001$, chi-square: 10.64} \\
\hline & No & $111(87.4 \%)$ & $56(78.9 \%)$ & $55(98.2 \%)$ & \\
\hline
\end{tabular}

In children with enuresis in our study, enuresis incidence in boys was higher than in girls, which is concordant with other studies. ${ }^{18,19}$ However, there was no significant difference between boys and girls.

In our study, the family history of enuresis, especially in siblings, was higher than in the control group, which is in agreement with other studies. ${ }^{20-22}$ This may indicate genetic inheritance as a risk factor for enuresis.

In a study by Huang et al, parental education was not found to be significantly associated with enuresis. ${ }^{18}$ In contrast, Hamed et al found that the education level of both mother and father has a significant association with enuresis. $^{22}$ In our study, only the father's education was significantly higher in children with enuresis.

In terms of family income levels, Özkan et al reported that enuresis was more prevalent in children with a low-income family, ${ }^{23}$ which is consistent with the studies by Hamed et $\mathrm{al}^{22}$ and Ferrara et al. ${ }^{24}$ In our work, however, the level of family income in the enuresis group was higher, which could reflect the greater attention of families with higher socioeconomic levels to their children's health conditions thus more doctor's visits to solve the issues.

As in our study, Bansal and Goyal found that a history of urinary tract infections was significantly associated with enuresis $(p<0.05) .^{20}$ Other studies of Egyptian, Turkish, Japanese, and Indian children confirmed this finding too. $12,22,25,26$

Various studies have shown that the occurrence of enuresis is also closely associated with sleep disorders. ${ }^{27-29}$ In the study by Özkan et al, sleep talking, sleep bruxism, and sleepwalking were significantly higher in children with enuresis, but the variable of difficulty falling asleep did not have any significant difference. ${ }^{23}$ Although in our study, the frequency of difficulty falling asleep was significantly higher in the enuresis group, sleep bruxism and sleep talking were not significantly different between the two groups.

It is hypothesized that one of the most important factors in the occurrence of enuresis can be difficulty waking up at 
Table 4 Logistics regression model to identify factors affecting enuresis

\begin{tabular}{|c|c|c|c|c|c|}
\hline \multicolumn{2}{|l|}{ Variable } & $\begin{array}{l}\text { Estimation of } \\
\text { coefficients }\end{array}$ & $\begin{array}{l}\text { Standard } \\
\text { error }\end{array}$ & $\begin{array}{l}\text { Chance ratio } \\
\text { ( } 95 \% \text { confidence interval) }\end{array}$ & p-Value \\
\hline \multirow[t]{4}{*}{ Father's education } & University & \multicolumn{4}{|l|}{ Reference } \\
\hline & Elementary & -0.92 & 0.73 & $0.39(0.09-1.66)$ & 0.20 \\
\hline & Middle school & -1.95 & 0.75 & $0.14(0.03-0.62)$ & 0.01 \\
\hline & High school & -0.12 & 0.74 & $0.89(0.20-3.84)$ & 0.87 \\
\hline \multirow[t]{3}{*}{ Income level } & High & \multicolumn{4}{|l|}{ Reference } \\
\hline & Low & -0.97 & 0.90 & $0.38(0.06-2.21)$ & 0.28 \\
\hline & Average & 0.02 & 0.90 & $1.02(0.17-6.02)$ & 0.98 \\
\hline \multirow[t]{4}{*}{ Family status of enuresis } & None & \multicolumn{4}{|l|}{ Reference } \\
\hline & Siblings & 1.59 & 0.46 & $4.94(2.01-12.19)$ & 0.001 \\
\hline & Mother & -0.09 & 0.68 & $0.91(0.24-3.48)$ & 0.89 \\
\hline & Father & 1.32 & 0.63 & $3.75(1.09-12.82)$ & 0.03 \\
\hline \multirow[t]{2}{*}{ Family issues } & No & \multicolumn{4}{|l|}{ Reference } \\
\hline & Yes & 2.03 & 0.57 & $7.59(2.47-23.27)$ & $<0.001$ \\
\hline \multirow[t]{2}{*}{ School problems } & No & \multicolumn{4}{|l|}{ Reference } \\
\hline & Yes & 1.74 & 0.58 & $5.72(1.84-17.78)$ & 0.003 \\
\hline \multirow{2}{*}{$\begin{array}{l}\text { History of urinary } \\
\text { tract infection }\end{array}$} & No & \multicolumn{4}{|l|}{ Reference } \\
\hline & Yes & 0.75 & 0.36 & $2.11(1.03-4.31)$ & 0.04 \\
\hline \multirow[t]{2}{*}{ History of pinworm } & No & \multicolumn{4}{|l|}{ Reference } \\
\hline & Yes & 1.98 & 1.09 & $7.15(0.85-60.37)$ & 0.07 \\
\hline \multirow[t]{2}{*}{ Difficulty falling asleep } & No & \multicolumn{4}{|l|}{ Reference } \\
\hline & Yes & 1.74 & 0.50 & $5.68(2.14-15.05)$ & $<0.001$ \\
\hline \multirow{2}{*}{$\begin{array}{l}\text { Difficulty falling asleep } \\
\text { after waking up }\end{array}$} & No & \multicolumn{4}{|l|}{ Reference } \\
\hline & Yes & 1.93 & 0.78 & $6.86(1.48-31.74)$ & 0.01 \\
\hline \multirow{2}{*}{$\begin{array}{l}\text { Hard to wake } \\
\text { the child up }\end{array}$} & No & \multicolumn{4}{|l|}{ Reference } \\
\hline & Yes & 1.49 & 0.42 & $4.47(1.95-10.23)$ & $<0.001$ \\
\hline \multirow{2}{*}{$\begin{array}{l}\text { Feeling tired after } \\
\text { waking up }\end{array}$} & No & \multicolumn{4}{|l|}{ Reference } \\
\hline & Yes & 1.75 & 0.47 & $5.74(2.29-14.41)$ & $<0.001$ \\
\hline \multirow{2}{*}{$\begin{array}{l}\text { Drowsiness during } \\
\text { the day }\end{array}$} & No & \multicolumn{4}{|l|}{ Reference } \\
\hline & Yes & 2.69 & 1.05 & $14.73(1.88-115.37)$ & 0.01 \\
\hline
\end{tabular}

night, which in our study, and several other studies, was significantly higher in the enuresis group. ${ }^{13,20}$ Wada et al reported that enuresis was directly linked to daytime drowsiness in children with nocturnal snoring. ${ }^{28}$ However, in our study, nocturnal snoring and sleep apnea were not significantly different between the two groups.

\section{Conclusion}

Enuresis is a common pediatric public health problem that is influenced by various factors, including psychological, physiological, and genetic factors. Our analysis showed that several factors from these different categories have a significant correlation with the incidence of enuresis in children. For prevention and proper management of enuresis, both parents and clinicians should be well informed about these significant risk factors.
Conflict of Interest

None declared.

\section{References}

1 Gomez Rincon M, Leslie SW, Lotfollahzadeh S. Nocturnal enuresis. Treasure Island (FL): StatPearls: StatPearls Publishing LLC; 2020

2 Prince E, Heys M. Nocturnal enuresis: an update on management. Drug Ther Bull 2020;58(02):25-29

3 Naiwen T, Baskin LS, Arnhym AM. Nocturnal enuresis in children: etiology and evaluation. In: Drutz E, ed. UpToDate. UpToDateWaltham, MA2020

4 Austin PF, Bauer SB, Bower W, et al. The standardization of terminology of lower urinary tract function in children and adolescents: update report from the standardization committee of the International Children's Continence Society. Neurourol Urodyn 2016;35(04):471-481

5 Graham KM, Levy JB. Enuresis. Pediatr Rev 2009;30(05):165-172, quiz 173 
6 Thurber S. Childhood enuresis: current diagnostic formulations, salient findings, and effective treatment modalities. Arch Psychiatr Nurs 2017;31(03):319-323

7 Fagundes SN, Lebl AS, Azevedo Soster L, Sousa E Silva GJ, Silvares EF, Koch VH. Monosymptomatic nocturnal enuresis in pediatric patients: multidisciplinary assessment and effects of therapeutic intervention. Pediatr Nephrol 2017;32(05):843-851

8 Nevéus T. Pathogenesis of enuresis: towards a new understanding. Int J Urol 2017;24(03):174-182

9 Ghahramani M, Basirymoghadam M, Ghahramani A. Nocturnal enuresis and its impact on growth. Iran J Pediatr 2008;18(02): $167-170$

10 Ghotbi N, Kheyrabadi GR. Enuresis: its prevalence and associated factors in primary school students in Sanandaj. Sci J Kurdistan Uni Med Sci 2001;5(04):30-34

11 Bower WF, Moore KH, Shepherd RB, Adams RD. The epidemiology of childhood enuresis in Australia. Br J Urol 1996;78(04):602-606

12 Ozden C, Ozdal OL, Altinova S, Oguzulgen I, Urgancioglu G, Memis A. Prevalence and associated factors of enuresis in Turkish children. Int Braz J Urol 2007;33(02):216-222

13 Tai HL, Chang YJ, Chang SCC, Chen GD, Chang CP, Chou MC. The epidemiology and factors associated with nocturnal enuresis and its severity in primary school children in Taiwan. Acta Paediatr 2007;96(02):242-245

14 Loeys B, Hoebeke P, Raes A, Messiaen L, De Paepe A, Vande Walle J. Does monosymptomatic enuresis exist? A molecular genetic exploration of 32 families with enuresis/incontinence. BJU Int 2002;90(01):76-83

15 Nørgaard JP, Djurhuus JC. The pathophysiology of enuresis in children and young adults. Clin Pediatr (Phila) 1993;32(Spec No, suppl):5-9

16 Azevedo Soster L, Alves R, Fagundes SN, Koch VHK, Bruni O. Sleep disturbances associated with sleep enuresis: a questionnaire study. Eur J Paediatr Neurol 2016;20(02):282-285

17 Arda E, Cakiroglu B, Thomas DT. Primary nocturnal enuresis: a review. Nephrourol Mon 2016;8(04):e35809

18 Huang H-M, Wei J, Sharma S, et al. Prevalence and risk factors of nocturnal enuresis among children ages 5-12 years in Xi'an, China: a cross-sectional study. BMC Pediatr 2020;20(01):305
19 Sarici H, Telli O, Ozgur BC, Demirbas A, Ozgur S, Karagoz MA. Prevalence of nocturnal enuresis and its influence on quality of life in school-aged children. J Pediatr Urol 2016;12(03):159. e1-159.e6

20 Bansal N, Goyal MB. Prevalence and factors affecting nocturnal enuresis among primary school children in Baddi, Himachal Pradesh, India. Int J Contemp Pediatrics 2020;7(03):607

21 Fockema MW, Candy GP, Kruger D, Haffejee M. Enuresis in South African children: prevalence, associated factors and parental perception of treatment. BJU Int 2012;110(11 Pt C, 11c): E1114-E1120

22 Hamed A, Yousf F, Hussein MM. Prevalence of nocturnal enuresis and related risk factors in school-age children in Egypt: an epidemiological study. World J Urol 2017;35(03): 459-465

23 Özkan S, Durukan E, Iseri E, Gürocak S, Maral I, Ali Bumin M. Prevalence and risk factors of monosymptomatic nocturnal enuresis in Turkish children. Indian J Urol 2010;26(02): 200-205

24 Ferrara P, Ruggiero A, Diociaiuti L, Paoletti FP, Chiozza ML, Caione P. Primary nocturnal enuresis and left-handedness. Scand J Urol Nephrol 2001;35(03):184-185

25 Solanki AN, Desai SG. Prevalence and risk factors of nocturnal enuresis among school age children in rural areas. Int $\mathrm{J}$ Res Med Sci 2014;2(01):202-205

26 Kajiwara M, Inoue K, Kato M, Usui A, Kurihara M, Usui T. Nocturnal enuresis and overactive bladder in children: an epidemiological study. Int J Urol 2006;13(01):36-41

27 Tsuji S, Takewa R, Ohnuma C, Kimata T, Yamanouchi S, Kaneko K. Nocturnal enuresis and poor sleep quality. Pediatr Int (Roma) 2018;60(11):1020-1023

28 Wada H, Kimura M, Tajima T, et al. Nocturnal enuresis and sleep disordered breathing in primary school children: potential implications. Pediatr Pulmonol 2018;53(11):1541-1548

29 Esposito M, Gallai B, Parisi L, et al. Primary nocturnal enuresis as a risk factor for sleep disorders: an observational questionnairebased multicenter study. Neuropsychiatr Dis Treat 2013; 9:437-443 